\title{
Nutritional Analysis of BRS Topázio Cotton Plants with Omission of Macronutrients
}

\author{
Felipe Guedes de Souza ${ }^{1}$, Lucia Helena Garófalo Chaves ${ }^{1}$, Allan Nunes Alves ${ }^{1}$, Jorge Alves de Sousa ${ }^{2}$ \\ $\&$ Ana Carolina Feitosa de Vasconcelos ${ }^{1}$ \\ ${ }^{1}$ Department of Agricultural Engineering, Federal University of Campina Grande, Campina Grande, Paraiba \\ State, Brazil \\ ${ }^{2}$ Department of Physics and Mathematics, Federal University of Campina Grande, Cuité, Paraiba State, Brazil \\ Correspondence: Lúcia Helena Garófalo Chaves, Federal University of Campina Grande, Avenue Aprigio \\ Veloso, 882, Campina Grande, CEP 58429-140, Paraiba State, Brazil. Tel: 55-83-2101-1186. E-mail: \\ lhgarofalo@hotmail.com
}

Received: December 2, 2017 Accepted: January 3, $2018 \quad$ Online Published: February 15, 2018

doi:10.5539/jas.v10n3p237 URL: https://doi.org/10.5539/jas.v10n3p237

\begin{abstract}
In order to verify the nutritional disorders caused by the lack of macronutrients in the BRS Topázio cotton plants, an experiment was carried out in a greenhouse of diagnosis by subtraction, in which the following nutrients were omitted: $\mathrm{N}, \mathrm{P}, \mathrm{K}, \mathrm{Ca}, \mathrm{Mg}$ and $\mathrm{S}$, with three replications totaling 21 experimental units. The omission of nutrients affected the production of phytomass in all treatments. The $\mathrm{N}$ content in cotton plants increased and decreased in the absence of $\mathrm{K}$ and $\mathrm{Ca}$, respectively. The content of $\mathrm{P}$ increased with the omission of $\mathrm{N}, \mathrm{K}, \mathrm{Mg}$, and decreased with omission of S. Regarding the content of K, it increased in the absence of S and decreased in the absence of N, $\mathrm{P}, \mathrm{K}$ and $\mathrm{Ca}$. The higher levels of $\mathrm{Ca}, \mathrm{Mg}$ and $\mathrm{S}$ in cotton plants were observed with the absence of $\mathrm{K}$.
\end{abstract}

Keywords: Gossypium hirsutum L., missing element, nutrient solution

\section{Introduction}

Cotton (Gossypium hirsutum L.) is a plant that has great economic and social importance worldwide being among the main crops in agribusiness in several parts of the world. Cotton oilseed stands out for a production of more than 20 million tons of fiber per year, being grown in more than 80 countries (Beltrão et al., 2010).

Brazil stands out as the fifth largest producer, sixth largest consumer and fourth largest exporter in relation to the other cotton producing countries. In this sense, in order to maintain this competitiveness and achieve high levels of productivity, it is necessary that the availability of nutrients is adequate to the plants optimal amount for its good development.

Cotton as any plant has its nutritional requirement determined by the amount of nutrients that is extracted during the life cycle with the intention of obtaining high yields. However, not all the nutrients that are supplied to the cotton are reverted to yields, because in the middle of this process there is a quantity of nutrients exported to the seeds and fibers, and another quantity remains in the crop residues. The mineral nutrition of cotton, which must be related to the climatic conditions and to the plant physiological processes, includes all macronutirents $(\mathrm{N}, \mathrm{P}, \mathrm{K}$, $\mathrm{Ca}, \mathrm{Mg}, \mathrm{S}$ ) and micronutrients (B, Fe, $\mathrm{Mn}, \mathrm{Zn}, \mathrm{Cu}, \mathrm{Mn}, \mathrm{Mo}, \mathrm{Cl}$ and $\mathrm{Ni}$ ), whose sources are the soil mineral reserve and fertilizers (Grespan \& Zancanaro, 1999).

Plant growth in the absence of any element considered essential for its development causes biochemical phenomena within plants that are expressed by typical symptoms. These symptoms are characterized in a quick way by the visual diagnosis, which consists in visually comparing the appearance (color, size, shape) of the sample (plant, branches, leaves) with the pattern. This diagnosis identifies a plant with deficiency or excess of some nutrient, or excess of some chemical element. However, the visible changes do not always allow the possibility of correction of the deficiency in the current agricultural year, may causing economic damages.

In this sense, several other nutritional status assessment techniques can be used, such as foliar diagnosis. This technique analyzes the nutrient content of leaves at a defined period of plant life and compares them with nutritional standards established in the literature. The main metabolic processes occur in the leaf; therefore, it is the organ that best represents the nutritional state of the plant (Faquin, 2002). For leaf diagnosis of cotton, leaves 
should be sampled in the growth period. Foliar diagnosis is based on actions that represent the great majority of studies and the diffusion of technology directed to the nutrition of plants (Silva, 2006).

The objective of this work was to evaluate the effect of omission of macronutrients in the nutritional state of cotton plants cultivar Topázio.

\section{Material and Methods}

\subsection{Experimental Site}

The experiment was carried out under greenhouse conditions of the Department of Agricultural Engineering of the Federal University of Campina Grande, situated at the local geographical coordinates $7^{\circ} 15^{\prime} 18^{\prime \prime}$ latitude S, $35^{\circ} 52^{\prime} 28^{\prime \prime} \mathrm{W}$ longitude and $550 \mathrm{~m}$ altitude, from June to August of 2016, using nutrient solution.

\subsection{Design and Treatments}

The experimental design was completely randomized, with seven treatments, i.e., T1: the complete solution proposed by Hoagland and Arnon (1950); from T2 to T7: the individual omission of nitrogen (N), phosphorus $(\mathrm{P})$, potassium $(\mathrm{K})$, calcium $(\mathrm{Ca})$, magnesium $(\mathrm{Mg})$ and sulphur $(\mathrm{S})$ in this solution, with three repetitions, containing one cotton plant, Topazio cultivar, in each experimental unit.

The complete solutions were prepared with P.A. reagent and deionized water. During the experimental period, $\mathrm{pH}$ and electrical conductivity (EC) measurements were taken in order to maintain $\mathrm{pH}$ values in the range of 6.0 to 7.0 and $\mathrm{EC}$ around $2.5 \mathrm{dS} \mathrm{cm}^{-1}$.

\subsection{Experimental Conduction}

Pre-germinated plants were placed in pot $(50 \mathrm{ml})$, containing the deionized water, which was aerated constantly during the experimental period and the respective treatments. Six days after germination, the seedlings were transferred to the complete nutrient solution of Hoagland and Arnon (1950), with 10\% of their ionic strength for an adaptation, which remained under constant aeration until the final stage of pot experimentation.

After this adaptation period, the plants were transplanted to plastic pots with $1 \mathrm{~L}$ capacity and the treatments were applied under the missing element technique. The nutrient solutions were changed weekly and their ionic strength increased gradually until reaching $100 \%$.

At the end of the experiment, at 50 days after sowing (DAS), the plants were harvested, separated in roots and aerial part (leaves, branches and stems), packed in paper bags and taken to drying in a forced circulation oven at $65^{\circ} \mathrm{C}$ until reaching constant weight, obtaining the weight of the dried phytomass. After this procedure, the plant material was ground in a Willey mill for the chemical analysis, determining the macronutrients contents in the dry matter of the aerial and roots part, according to the method described by Bataglia et al. (1983).

\subsection{Statistical Analysis}

The data were submitted to analysis of variance and comparison of averages, using the Tukey test at the level of 1 (\%) probability, applying the SISVAR computer program (Ferreira, 2011).

\section{Results and Discussion}

The omission of N, P, K and Ca significantly reduced the dry matter of cotton plants around $90 \%$ in relation to the complete treatment (Figure 1), corroborating Gondim et al. (2016). These authors observed a reduction in the dry matter of the corn plant, BRS 1030 cultivar, with the deficiency of N, P, K and Ca. 
A
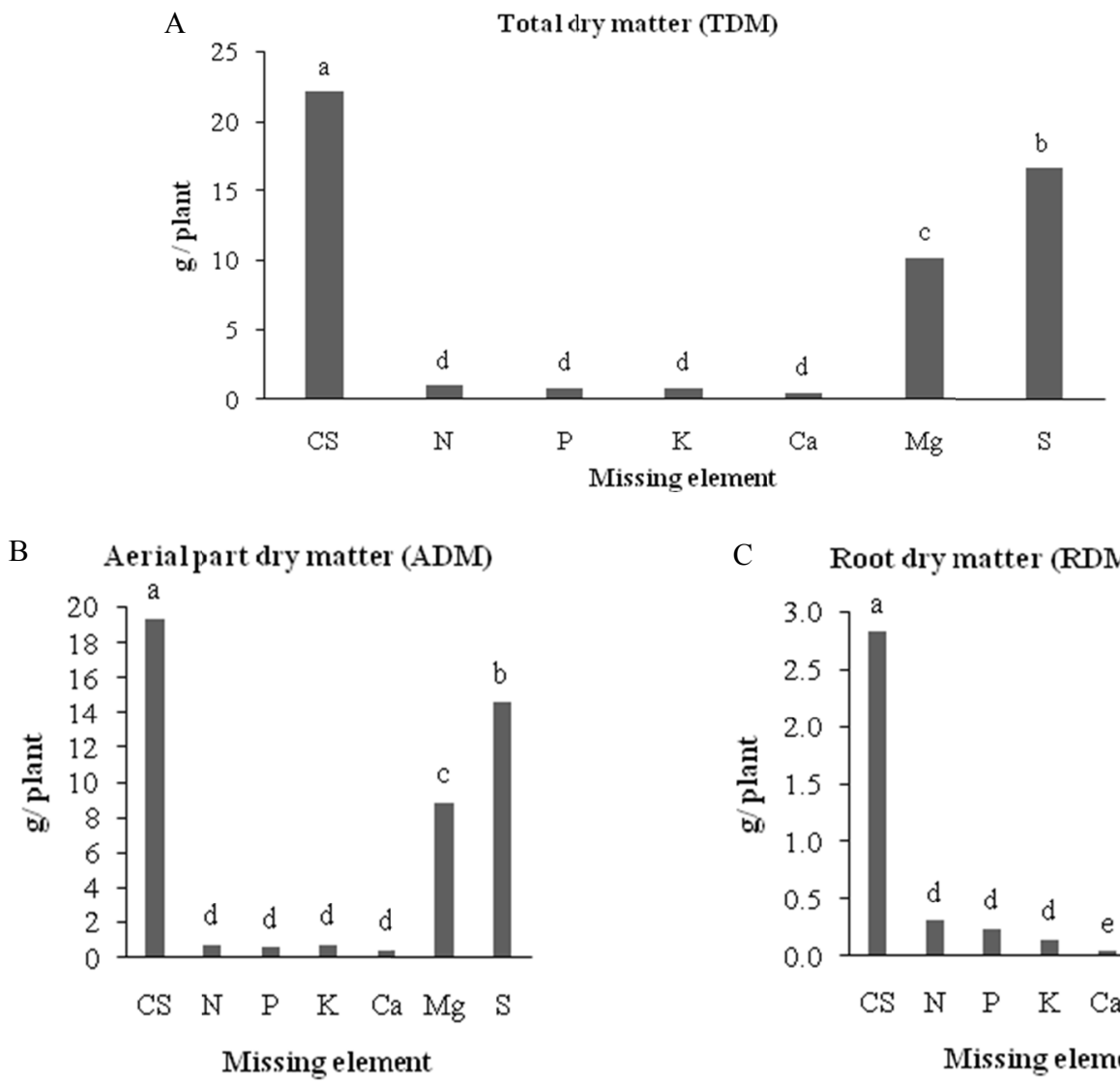

C Root dry matter (RDM)

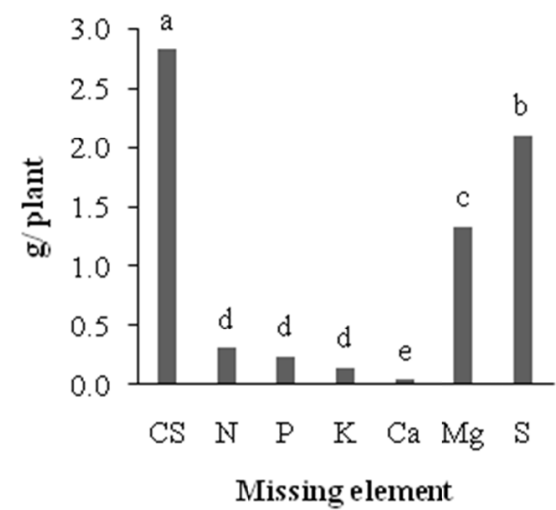

Figure 1. Total (A), aerial part (B) and root (C) dry matter yield of cotton cultivated with complete solution (CS) and with the omission of nutrients of nitrogen $(\mathrm{N})$, phosphorus $(\mathrm{P})$, potassium $(\mathrm{K})$, calcium $(\mathrm{Ca})$, magnesium

$(\mathrm{Mg})$ and sulfur $(\mathrm{S})$ after 50 DAS. Means (for each date) followed by the same letter do not differ from each other

Fifty days after sowing (DAS), the total dry matter of the cultivated plants in the absence of Mg and of S was 10.2 and $16.7 \mathrm{~g}$ per plant, which means a reduction of $54 \%$ and $25 \%$ for $\mathrm{Mg}$ and $\mathrm{S}$, respectively compared to MST (22.14 g) of the plants grown in complete solution (Figure 1). These results corroborated partially Prado et al. (2007). These authors, studying sorghum crop, found that the omission of magnesium in the plants resulted in a significant reduction in the dry matter production when compared to the data found in the plants with complete solution, already in relation to the sulfur there was no significant reduction.

On the other hand, Prado and Leal (2006), studying the performance of sunflower plants in nutrient solution, observed that sulfur and magnesium did not suffer significant reductions when compared to the complete solution.

The dry matter production of the aerial part and the roots of the plants cultivated with the omission of the nutrients were significantly reduced in relation to the complete treatment, corroborating Prado et al. (2007) and Silva et al. (2009) studying sorghum and Jatropha curcas, respectively.

The lack of calcium in the nutrient solution burned the plant pointers, which were not recovered during the experiment to the point of death. Thus, these plants did not develop showing the lowest values of dry matter.

The lack of $\mathrm{N}$ in the nutrient solution reduced the dry matter of the plants, since, according to Marschner (1995) and Malavolta et al. (1997), nitrogen is present in amino acids structure, proteins, nitrogen bases, nucleic acids, enzymes, coenzymes, vitamins, pigments and byproducts. In addition, nitrogen participates in processes such as ionic absorption, photosynthesis, respiration, multiplication and cellular differentiation, which interfere directly or indirectly in the development of the plant. 
Potassium exerts an important role in plant metabolism (Malavolta et al., 1997); therefore, its absence in the nutrient solution influenced the growth of cotton plants, reducing the dry matter of the plants when compared to the complete treatment.

The omission of phosphorus reduced plant dry matter due to reduced nucleic acid and protein synthesis, inducing the accumulation of soluble nitrogen compounds $(\mathrm{N})$ in the tissue. Moreover, there is a delay in cell growth, resulting in decreased height, delayed emergence, reduced root development and dry matter (Grant et al., 2001).

The nutrient content of the cotton plants evaluated at the end of the experiment, as a function of the treatments studied, influenced significantly as can be seen in Table 1.

Table 1. Summary of the analyses of variance for nutrient content in cotton plants depending on the treatments

\begin{tabular}{llllllll}
\hline \multirow{2}{*}{ Source of Variation } & \multirow{2}{*}{$\mathrm{DF}$} & \multicolumn{6}{c}{ Mean Square } \\
\cline { 3 - 8 } & & $\mathrm{N}$ & $\mathrm{P}$ & $\mathrm{K}$ & $\mathrm{Ca}$ & $\mathrm{Mg}$ & $\mathrm{S}$ \\
\hline Treatments & 6 & $2.62^{* *}$ & $0.04^{* *}$ & $2.00^{* *}$ & $5.99^{* *}$ & $0.48^{* *}$ & $0.13^{* *}$ \\
$\mathrm{VC}$ & & 9.24 & 11.01 & 16.04 & 6.45 & 2.49 & 2.25 \\
\hline
\end{tabular}

The lowest concentrations of nitrogen, phosphorus, potassium, calcium, magnesium and sulphur were observed in the plants cultivated with the omission of these elements, respectively (Figure 2).
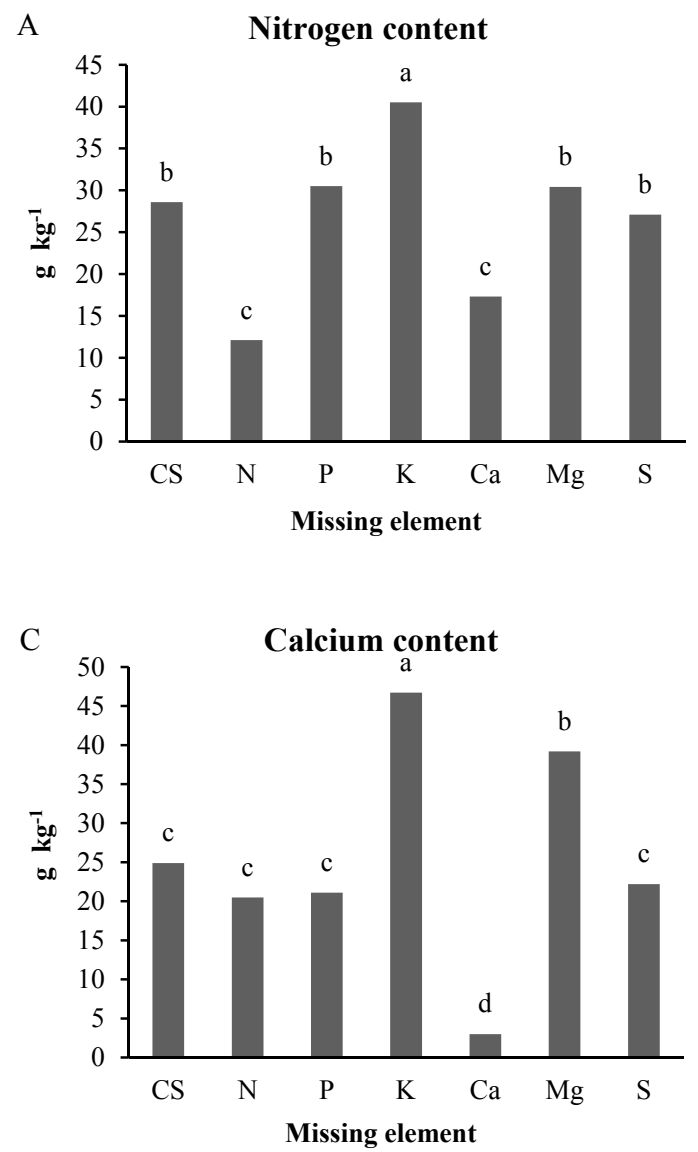
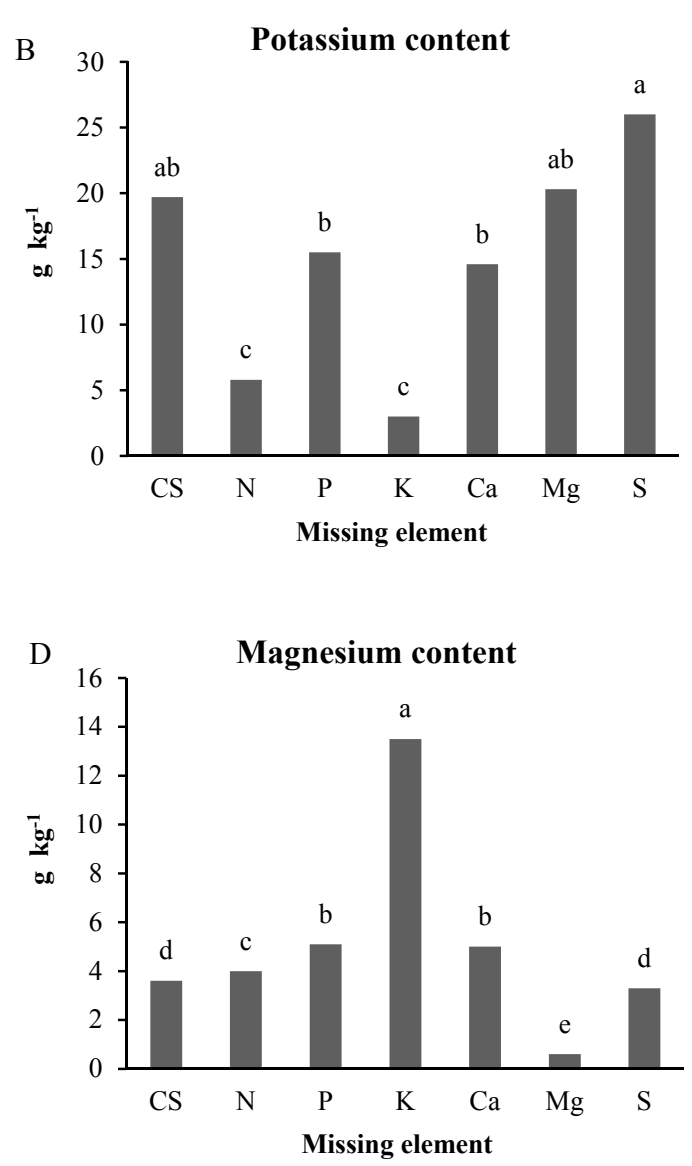

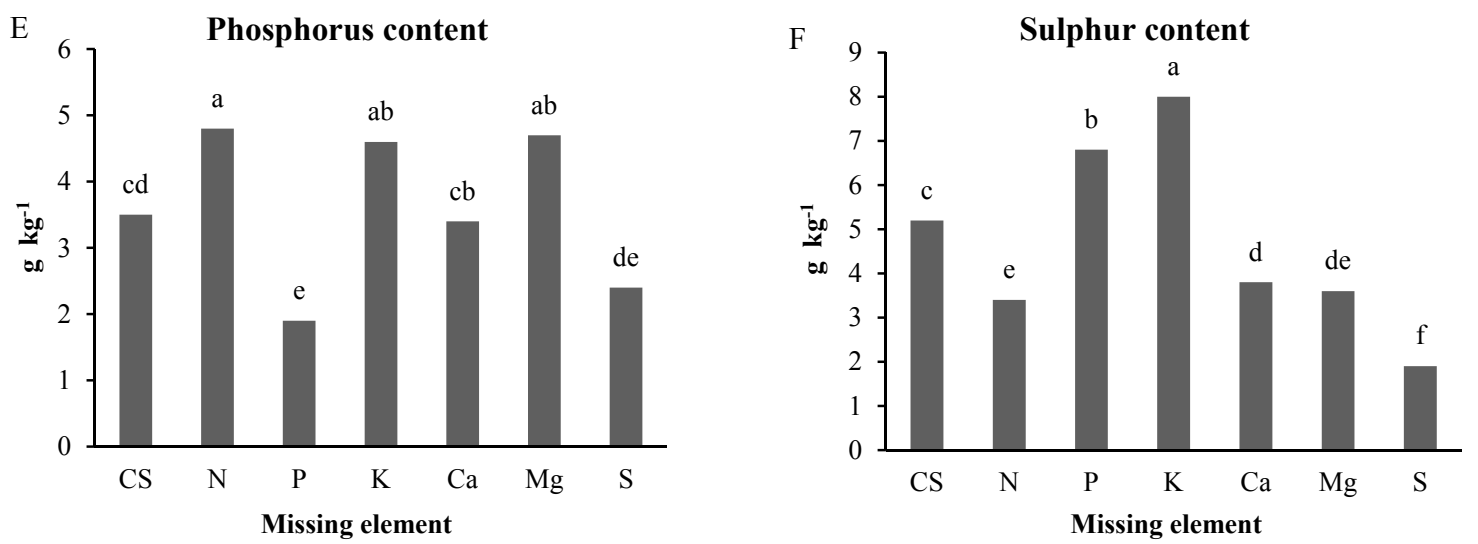

Figure 2. Mean nitrogen (A) content $\left(\mathrm{g} \mathrm{kg}^{-1}\right)$, potassium (B), calcium (C), magnesium (D), phosphorus (E), and sulphur $(\mathrm{F})$ in cotton plants grown in complete solution and with omission of the respective macronutrients

In the treatment without $\mathrm{K}$, the nitrogen concentration of $40.5 \mathrm{~g} \mathrm{~kg}^{-1}$ was $42 \%$ higher than that verified for the complete treatment (Figure 2A) probably because the deficiency of potassium in plants causes an accumulation of soluble nitrogenous compounds, including aminesa and putrescins (Epstein, 1975), increasing the nitrogen content, as it was observed in this study. As a consequence, it can cause lesions corresponding to the toxicity. This trend was observed by Prado and Leal (2006) studying nutritional disorders by deficiency in sunflower var. Catissol-01.

On the other hand, the treatment without Ca resulted in the lowest concentration of nitrogen, i.e., $17.3 \mathrm{~g} \mathrm{~kg}^{-1}, \mathrm{a}$ value $60 \%$ lower than it was observed in the complete treatment. This can be justified by the fact that calcium

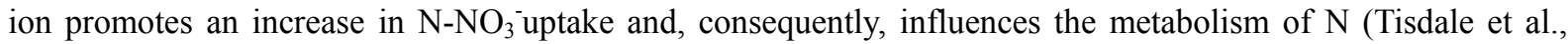
1993). Thus, the omission of calcium in plants decreased absorption of nitrogen. Similar results to the decrease in nitrogen absorption in the absence of the calcium element were observed by Santi et al. (2006), in the cultivation of sorghum, and by Prado and Vidal (2008), in maize. Therefore, when the $\mathrm{N}$ content in the plant presents low values, several physiological processes have been compromised that lead to visual symptoms of deficiency, as previously described (Souza et al., 2017).

Plants submitted to the omission of $\mathrm{N}$ presented potassium content reduced by around $70 \%$ (Figure $2 \mathrm{~B}$ ). It is already known that nitrogen supply increases potassium uptake and also increases protein and soluble amino acid contents, resulting in increased production (Lavres Junior et al., 2005). In this sense, the absence of nitrogen reduces the potassium uptake and, as a consequence, the $\mathrm{K}$ content in plants.

The treatments without $\mathrm{P}$ and $\mathrm{Ca}$ suffered a reduction in the potassium content when compared to the complete solution. However, this reduction was not significant and presented the same characteristics observed for the complete solution.

Regarding the treatment with omission of the $\mathrm{S}, 26 \mathrm{~g} \mathrm{~kg}^{-1}$ of the $\mathrm{K}$ content in the plants was verified, a value $32 \%$ higher than that one verified in the control treatment. This fact is due the occurrence of a higher production of dry matter and high $\mathrm{K}$ content in these plants.

The highest levels of calcium in plants corresponded to the absence of potassium and magnesium in the nutrient solution (Figure 2C). According to Malavolta (2008), this fact is explained by the absence of the inhibition mechanisms between calcium and magnesium and between calcium and potassium. Regarding calcium and magnesium, the effect is antagonistic, i.e., the excess of one impairs the absorption of the other, and the absence of one increases the absorption of the other (Prado, 2008).

The omission of $\mathrm{N}, \mathrm{P}, \mathrm{K}$ and $\mathrm{Ca}$ in the nutrient solution increased the $\mathrm{Mg}$ content in the plants when compared to the plants that received the complete nutrient solution, highlighting the treatment without $\mathrm{K}$, since it concentrated the highest magnesium content in relation to the other treatments (Figure 2D). According to Rosolem (2005), this accumulation can be explained by the dilution effect, where the reduction of the potassium nutrient causes an increase of the magnesium content. In addition to this effect of dilution, the lack of competitiveness between the magnesium, calcium and potassium also justifies the increase of the magnesium content in these plants. 
Phosphorus content, 4.8, 4.6 and $4.7 \mathrm{~g} \mathrm{~kg}^{-1}$ in plants cultivated without nitrogen, potassium and magnesium, respectively, were above $37.1 \%, 31.4 \%$ and $34.3 \%$ of that observed in the plants of the complete treatment (Figure 2E). Probably, this was due to the competitive inhibition between nitrogen and phosphorus and between magnesium (enzymatic activator in almost all phosphorylative enzymes) and phosphorus, according to Wilkinson et al. (1999), and Marschner (1995), respectively, increasing phosphorus content when nitrogen and magnesium were absent in the nutrient solution. Plants cultivated without sulphur in the nutrient solution had a concentration of $2.4 \mathrm{~g} \mathrm{~kg}^{-1}$ of $\mathrm{P}, 31 \%$ lower than the $\mathrm{P}$ content found in the complete treatment. In this case, it is likely that the absence of $\mathrm{S}_{-} \mathrm{SO}_{4}^{-2}$ has disadvantaged the absorption of $\mathrm{P}$, characterizing in principle, the occurrence of a synergistic effect, where the absence of one decreases the absorption of the other.

The sulphur content of plants (Figure 2F) grown without $\mathrm{P}$ and without $\mathrm{K}$ in the nutrient solution increased significantly by $31 \%$ and $53 \%$, respectively, when compared to the content observed in plants submitted to the complete treatment. Probably, the absence of $\mathrm{P}$ favored the absorption of $\mathrm{S}$ due to the occurrence of a competitive effect. In contrast, the levels of $\mathrm{S}$ in the plants with omission of $\mathrm{N}, \mathrm{Ca}, \mathrm{Mg}$ and $\mathrm{S}$ were reduced in comparison to contents observed in plants grown with complete solution.

\section{Conclusion}

The phytomass production of cotton submitted to all treatments without one macronutrient in the nutrient solution decreased, causing damage to the development of plants.

Regarding nutritional performance, $\mathrm{N}$ content in cotton plants increased in the absence of $\mathrm{K}$, and decreased in the absence of $\mathrm{K}$ and $\mathrm{Ca}$. The content of $\mathrm{P}$ increased with the omission of $\mathrm{N}, \mathrm{K}$, and $\mathrm{Mg}$; and decreased with omission of S. Regarding the content of K, it increased in the absence of $\mathrm{S}$ and decreased in the absence of N, P, $\mathrm{K}$ and $\mathrm{Ca}$. The higher levels of $\mathrm{Ca}, \mathrm{Mg}$ and $\mathrm{S}$ in cotton plants were observed with the absence of $\mathrm{K}$.

\section{References}

Bataglia, O. C., Furlani, A. M. C., Teixeira, J. P. F., Furlani, P. R., \& Gallo, J. R. (1983). Métodos de análise química de plantas (Boletim Técnico, 78). Campinas: Instituto Agronômico.

Beltrão, N. E. M., Oliveira, M. I. P., Lucena, A. M. A., Santos, J. W., \& Sousa, J. G. (2010). Modificações no algodoeiro herbáceo super precoce sob influência do cloreto de mepiquat. Revista Brasileira de Oleaginosas e Fibrosas, 14, 19-27. Retrieved from http://ainfo.cnptia.embrapa.br/digital/bitstream/item/ 19182/1/RBOF_1429-35.pdf

Epstein, E. (1975). Nutrição mineral de plantas, princípios e perspectivas. São Paulo: Universidade de São Paulo.

Faquin, V. (2002). Diagnose do estado nutricional das plantas. Lavras: UFLA/FAEPE.

Ferreira, D. F. (2011). Sisvar: A computer statistical analysis system. Ciência e Agrotecnologia, 35, 1039-1042. http://doi.org/10.1590/S1413-70542011000600001

Gondim, A. R. O., Prado, R. M., Alves, A. U., \& Fonseca, I. M. (2016). Crescimento inicial do milho cultivar BRS 1030 sob omissão de nutrientes em solução nutritiva. Revista Ceres, 63, 706-714. https://doi.org/ 10.1590/0034-737x201663050016

Grant, C. A., Flaten, D. N., Tomasiewicz, D. J., \& Sheppar, S. C. (2001). A importância do fósforo no desenvolvimento inicial da planta. Informações Agronômicas, 95, 1-5.

Grespan, S. L., \& Zancanaro, L. (1999). Nutrição e adubação do algodoeiro no Mato Grosso. Mato Grosso: Liderança e competitividade (p. 182, Boletim, 3). Rondonópolis: Fundação MT.

Hoagland, D. R., \& Arnon, D. I. (1950). The water culture method for growing plants without soil. Berkeley, CA: Agric. Exp. Stn., Univ. of California.

Lavres Junior, J., Boaretto, R. M., Silva, M. L. S., Correia, D., Cabral, C. P., \& Malavolta, E. (2005). Deficiências de macronutrientes no estadonutricional da mamoneira cultivar IRIS. Pesquisa Agropecuária Brasileira, 40, 145-151. https://doi.org/10.1590/S0100-204X2005000200007

Malavolta, E. (2008). O futuro da nutrição de plantas o futuro da nutrição de plantas tendo em vista aspectos agronômicos, econômicos e ambientais. Informações Agronômicas, 121, 1-10.

Malavolta, E., Vitti, G. C., \& Oliveira, S. (1997). Avaliação do estado nutricional das plantas: princípios e aplicações. Piracicaba: Potafos.

Marschner, P. (1995). Mineral nutrition of higher plants. New York: Academic Press. 
Prado, R. M. (2008). Nutrição de Plantas. São Paulo: Editora da UNESP.

Prado, R. M., \& Leal, R. M. (2006). Desordens nutricionais por deficiência em girassol var. catissol-01. Pesquisa Agropecuária Tropical, 36, 187-193.

Prado, R. M., \& Vidal, A. A. (2008). Efeitos da omissão de macronutrientes em solução nutritiva sobre o crescimento e a nutrição do milheto. Pesquisa Agropecuária Tropical, 38, 208-214.

Prado, R.M., Romualdo, L. M., \& Rozane, D. E. (2007). Omissão de macronutrientes no desenvolvimento e no estado nutricional de plantas de sorgo (cv. BRS 3010) cultivadas em solução nutritiva. Científica, 35, 122-128.

Rosolem, C. A. (2005). Interação do potássio com outros íons. In T. Yamada \& T. L. Roberts (Eds.), Potássio na agricultura brasileira (pp. 239-260). Piracicaba: Potafos.

Santi, A., Camargos, S. L., Scaramuzza, W. L. M. P., \& Scaramuzza, J. F. (2006). Deficiências de macronutrientes em sorgo. Ciência e Agrotecnologia, 30, 228-233. https://doi.org/10.1590/S1413-7054200 6000200006

Silva, M. A. C. (2006). Métodos de avaliação do estado nutricional para o algodoeiro no centro-oeste do Brasil (75 f. Tese, doutorado, Universidade Estadual Paulista, Faculdade de Ciências Agrárias e Veterinárias).

Silva, M. A. C., Natale, W., Malheiros, E. B., \& Pavinato, A. (2009). Estabelecimento e validação de normas DRIS para a cultura do algodão no centro-oeste do Brasil. Acta Scientiarum Agronomy, 31, 93-99. https://doi.org/10.4025/actasciagron.v31i1.6636

Souza, F. G., Chaves, L. H. G., Alves, A. N., \& Souza, J. A. (2017). Macronutrients Omission in the Growth of Cotton, BRS Topázio Cultivar Grown in Nutritious Solution. American Journal of Plant Sciences, 8, 2345-2357. https://doi.org/10.4236/ajps.2017.810157

Tisdale, S. L., Nelson, W. L., Beaton, J. D., \& Havlin, J. L. (1993). Soil fertility and fertilizers. New York: Macmillan.

Wilkinson, S. R., Grunes, D. L., \& Sumner, M. E. (1999). Nutrient Interactions in Soil and Plant Nutrition. In M. E. Sumner (Ed.), Handbook of Soil Science (pp. 89-112). Boca Raton, FL: CRC Press.

\section{Copyrights}

Copyright for this article is retained by the author(s), with first publication rights granted to the journal.

This is an open-access article distributed under the terms and conditions of the Creative Commons Attribution license (http://creativecommons.org/licenses/by/4.0/). 